\title{
Isobutylhydroxyamides from Zanthoxylum bungeanum and Their Suppression of NO Production
}

\author{
Yuan Wang ${ }^{1,2}$, Chun-Huan Li ${ }^{1}$, Bo Luo ${ }^{1}$, Ya Nan Sun ${ }^{3}$, Young Ho Kim ${ }^{3}$, An-Zhi Wei ${ }^{2, *}$ and \\ Jin-Ming Gao ${ }^{1, *}$ \\ 1 Shaanxi Key Laboratory of Natural Products \& Chemical Biology, College of Science, \\ Northwest A\&F University, Yangling 712100, Shaanxi, China; angsoneaven@163.com (Y.W.); \\ chunhuanli@nwsuaf.edu.cn (C.-H.L.); luobo2011@163.com (B.L.) \\ 2 College of Forestry, Northwest A\&F University, Yangling 712100, Shaanxi, China \\ 3 College of Pharmacy, Chungnam National University, Daejeon 305-764, Korea; yanansun@163.com (Y.N.S.); \\ yhk@cnu.ac.kr (Y.H.K.) \\ * Correspondence: anzhiwei@nwsuaf.edu.cn (A.-Z.W.); jinminggao@nwsuaf.edu.cn (J.-M.G.); \\ Tel.: +86-29-87082211 (A.-Z.W.); +86-29-87092335 (J.-M.G.)
}

Academic Editor: Isabel C. F. R. Ferreira

Received: 18 September 2016; Accepted: 10 October 2016; Published: 23 October 2016

\begin{abstract}
Four new unsaturated aliphatic acid amides, named zanthoamides A-D (1-4), and eight known ones-tetrahydrobungeanool (5), ZP-amide A (6), ZP-amide B (7), ZP-amide C (8), ZP-amide D (9), ZP-amide E (10), bugeanumamide A (11), and (2E,7E,9E)- $N$-(2-hydroxy-2-methylpropyl)6,11-dioxo-2,7,9-dodecatrienamide (12)—were isolated from the pericarps of Zanthoxylum bungeanum. The structures of these compounds were elucidated by extensive use of spectroscopic methods, including HRESIMS, 1D and 2D NMR analyses and comparison with previously reported data. Compound 4 contained a rare $\mathrm{C}_{6}$ fatty acid unit with an acetal group. Results revealed that compounds $1,5,6$, and 12 showed inhibitory effects on nitric oxide (NO) production in LPS-stimulated RAW 264.7 macrophages, with $\mathrm{IC}_{50}$ values of $48.7 \pm 0.32,27.1 \pm 1.15,49.8 \pm 0.38$, and $39.4 \pm 0.63 \mu \mathrm{M}$, respectively, while the other compounds were inactive $\left(\mathrm{IC}_{50}>60 \mu \mathrm{M}\right)$. They could contribute to the anti-inflammatory effects of $Z$. bungeanum by suppression of $\mathrm{NO}$ production.
\end{abstract}

Keywords: Huajiao; Zanthoxylum bungeanum; unsaturated alkylamides; isobutylhydroxyamides; sanshools; NO inhibitory activity; anti-inflammatory

\section{Introduction}

The genus Zanthoxylum (family Rutaceae), commonly called "prickly ash", comprises more than 200 species distributed worldwide. Phytochemical studies of this genus have revealed a variety of biologically active secondary metabolites, including alkaloids, aromatic and aliphatic amides, lignans and coumarins with antitumor, anti-inflammation, and anesthetic properties [1-3]. Zanthoxylum bungeanum Maxim is an aromatic tree and shrub, which is native to the provinces of Sichuan, Shaanxi, Yunnan, Guizhou, Guanxi, and Guandong in southwestern China. The fruits of this species, called "da hong pao" (big red robe), are the most popular red huajiao commercial product. Red huajiao, the pericarps of the fruits of Z. bungeanum have been utilized as a pungent foodstuff and also as a kind of traditional Chinese medicine for the treatment of vomiting, toothache, stomachache, abdominal pain, and diarrhea [4]. Previous phytochemical research on Z. bungeanum has focused on the essential oils, coumarins, flavonoids, aliphatic amides (classified as sanshools), and alkaloids of the fruits and leaves [5-9].The huajiao extracts have great potential for applications in savory and sweet goods and beverages. Some of the aliphatic acid amides display antioxidant activities, modulatory effects on relaxing the circle muscle of the gastric body ( $\beta$-and $\gamma$-sanshool), 
anthelmintic, cytotoxic properties [10-12], as well as anti-type-1 diabetes (i.e., $\gamma$-sanshool) [13] and anti-tumor effects [14]. In addition, three aliphatic acid amides ( $\beta-, \gamma$ - and hydroxy- $\beta$-sanshool) exhibited human acyl-CoA: cholesterol acyltransferase inhibitory activities [15], and tumuramide $C$, ZP-amide A, and ZP-amide D exerted significant effects on PPAR transactivational activity [16]. Most recently, Hofmann et al. [1] have shown that the all-trans-configured amides hydroxy- $\beta$-sanshool and hydroxy- $\gamma$-isosanshool from Z. piperitum induced a numbing and anesthetic sensation. Our recent studies have showed that several alkylamides from cultivated Z. bungeanum pericarps possessed nerve growth factor-potentiating activity [17].

As part of our further search for bioactive substances from medicinal plants [18-21], our bioassays indicated that the $\mathrm{CHCl}_{3}$-soluble material of a crude $\mathrm{EtOH}$ extract of $\mathrm{Z}$. bungeanum pericarps displayed inhibitory activity against nitric oxide (NO) production in LPS-activated RAW264.7 macrophages. Further phytochemical investigation of the $\mathrm{CHCl}_{3}$-soluble material of $\mathrm{Z}$. bungeanum led to the isolation of four new alkylamides, named zanthoamides A-D (1-4), and eight known ones 5-12 (Figure 1). Here, we describe the isolation and structure elucidation of the compounds 1-12 and their NO inhibitory activity in LPS-stimulated RAW 264.7 cells.

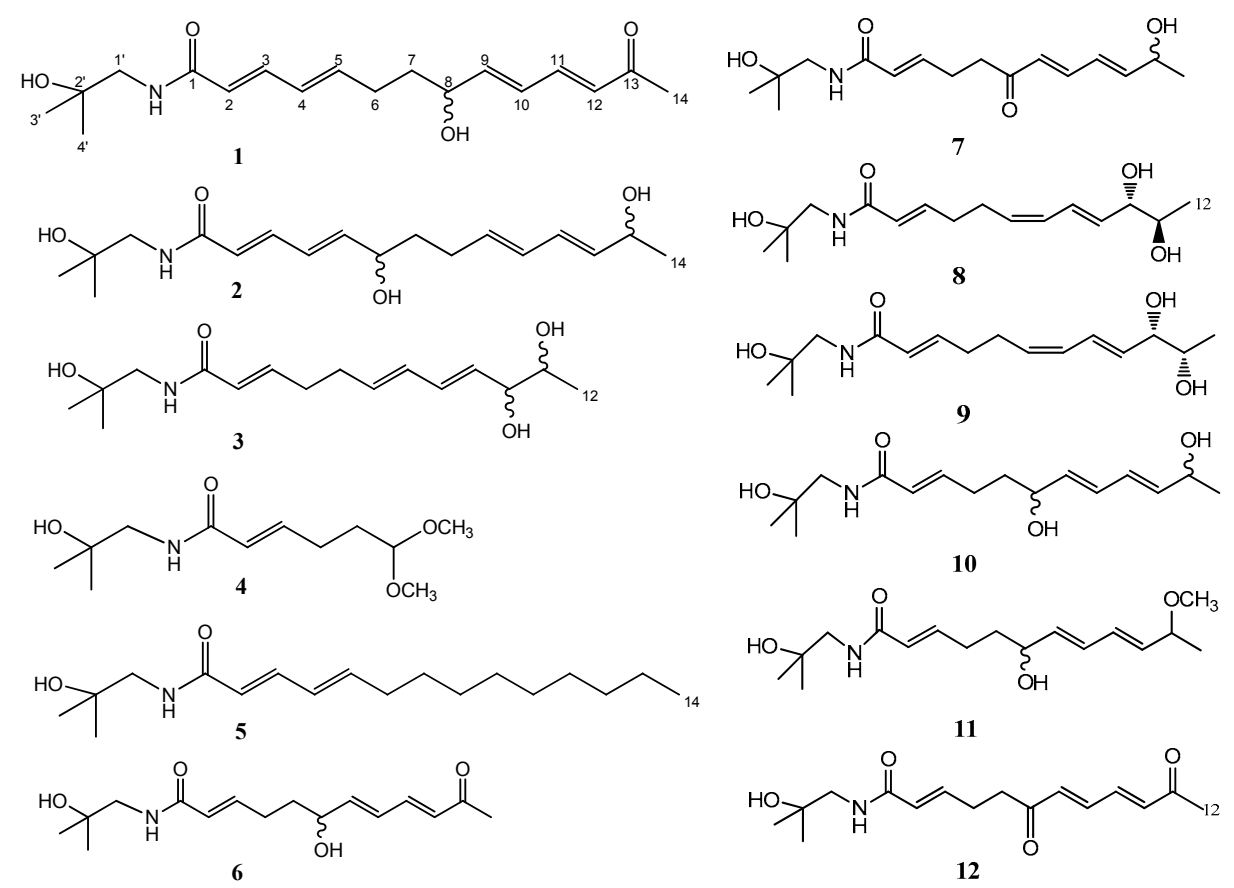

Figure 1. Chemical structures of compounds 1-12.

\section{Results and Discussion}

\subsection{Compound Characterization}

The $\mathrm{CHCl}_{3}$-soluble extract of the $95 \%$ ethanolic residue of the air-dried Z. bungeanum fruits was subjected to various separation procedures, leading to the isolation of four new isobutylhydroxyamides 1-4, together with eight known congeners including tetrahydrobungeanool (5) [5], ZP-amide A (6) [7], ZP-amide B (7), ZP-amide C (8), ZP-amide D (9), ZP-amide E (10) [7], bugeanumamide A (11) [16], and (2E,7E,9E)-N-(2-hydroxy-2-methylpropyl)-6,11-dioxo-2,7,9-dodecatrienamide (12) [4] (Figure 1). The structures of known compounds 5-12 were identified by their spectroscopic data and comparison with literature data. All isolated compounds possessed maximal UV absorptions near $230 \mathrm{~nm}$, consistent with the presence of a conjugated amide [14].

Compound 1 was obtained as a pale yellow syrup. Its molecular formula was determined as $\mathrm{C}_{18} \mathrm{H}_{27} \mathrm{NO}_{4}$ by HRESIMS at $m / z 344.1810$ [M $\left.+\mathrm{Na}\right]^{+}$(calcd. for $\mathrm{C}_{18} \mathrm{H}_{27} \mathrm{NO}_{4} \mathrm{Na}, 344.1838$ ), 
indicating six degrees of unsaturation. The IR spectrum displayed characteristic absorptions of hydroxyl and amide $\mathrm{NH}\left(3370 \mathrm{~cm}^{-1}\right)$ and amide $\left(1665 \mathrm{~cm}^{-1}\right)$ groups. The ${ }^{13} \mathrm{C}-\mathrm{NMR}$ and DEPT spectra (Table 1$)$ demonstrated 18 carbon resonance, which were classified as three methyls $\left(\delta_{C} 27.2 \times 2\right.$, $27.0)$, three methylenes with one of them occurring relatively downfield $\left(\delta_{C} 51.2\right)$, nine methines, including one oxygenated carbon $\left(\delta_{C} 71.8\right)$, and eight olefinic ones $\left(\delta_{C} 148.2,145.4,143.2,142.4,131.2\right.$, $130.3,128.9,123.2)$, an amide carbon $\left(\delta_{C} 169.4\right)$ and a ketonic carbon $\left(\delta_{C} 201.5\right)$, and one oxygenated quaternary carbon $\left(\delta_{C} 71.7\right)$. These data were consistent with the resonances observed in the ${ }^{1} \mathrm{H}-\mathrm{NMR}$ spectrum. The ${ }^{1} \mathrm{H}-\mathrm{NMR}$ spectrum of 1 revealed three tertiary methyl signals at $\delta_{\mathrm{H}} 1.18,1.18$, and 2.28 (each $3 \mathrm{H}$ of singlet). Meanwhile, eight olefinic protons at $\delta_{\mathrm{H}} 6.01,7.14,6.18,6.14,6.27,6.44,7.29$, and 6.15, and an oxygenated methine proton at $\delta_{\mathrm{H}} 4.22(\mathrm{~m})$, were clearly visible. Other overlapping proton resonances occurred between $\delta_{\mathrm{H}} 1.66$ and 2.28, resulting from either methyl or methylene protons. Comparison of the ${ }^{1} \mathrm{H}$ - and ${ }^{13} \mathrm{C}-\mathrm{NMR}$ data (Table 1 ) of $\mathbf{1}$ with two known compounds ( 5 and $\mathbf{6}$ ) indicated that $\mathbf{1}$ was an unsaturated fatty acid amide bearing an $\mathrm{N}$-hydroxylisobutyl moiety.

Table 1. ${ }^{1} \mathrm{H}-\mathrm{NMR}(500 \mathrm{MHz})$ and ${ }^{13} \mathrm{C}-\mathrm{NMR}(125 \mathrm{MHz})$ data for $1-3$ in $\mathrm{MeOH}-d_{4}(\delta \mathrm{ppm})$.

\begin{tabular}{|c|c|c|c|c|c|c|}
\hline \multirow{2}{*}{ No. } & \multicolumn{2}{|l|}{1} & \multicolumn{2}{|l|}{2} & \multicolumn{2}{|l|}{3} \\
\hline & $\delta_{\mathrm{H}}(J$ in $\mathrm{Hz})$ & $\delta_{C}{ }^{a}$ & $\delta_{H}(J$ in $\mathrm{Hz})$ & $\delta_{C}{ }^{a}$ & $\delta_{H}(J$ in $\mathrm{Hz})$ & $\delta_{C}{ }^{a}$ \\
\hline 1 & & 169.4 & & 169.5 & & 169.0 \\
\hline 2 & $6.01 \mathrm{~d}(15.1)$ & 123.2 & $6.0 \mathrm{~m}$ & 123.1 & $5.29 \mathrm{~d}(15.0)$ & 125.1 \\
\hline 3 & $7.14 \mathrm{dd}(15.7,10.7)$ & 142.4 & $7.14 \mathrm{dd}(15.1,10.7)$ & 142.4 & $6.80 \mathrm{dt}(15.6,6.5)$ & 145.0 \\
\hline 4 & $6.23 \mathrm{dd}(15.7,10.7)$ & 130.3 & $6.25 \mathrm{dd}(15.1,10.7)$ & 130.1 & $2.30 \mathrm{dt}(12.5,6.5)$ & 32.8 \\
\hline 5 & $6.18 \mathrm{dt}(15.7,10.2)$ & 143.2 & $5.70 \mathrm{dd}(15.1,7.4)$ & 143.1 & $2.25 \mathrm{dt}(12.5,6.5)$ & 32.4 \\
\hline 6 & 2.28 overlap & 29.8 & $6.09 \mathrm{dd}(13.1,7.4)$ & 72.4 & $5.70 \mathrm{dt}(15.3,7.0)$ & 133.2 \\
\hline 7 & $1.66 \mathrm{~m}$ & 37.0 & $1.63 \mathrm{~m}$ & 37.4 & $6.12 \mathrm{dd}(15.3,10.6)$ & 132.1 \\
\hline 8 & $4.22 \mathrm{q}(6.0)$ & 71.8 & $2.23 \mathrm{td}(14.8,7.4)$ & 29.9 & $6.23 \mathrm{dd}(15.3,10.6)$ & 131.9 \\
\hline 9 & $6.28 \mathrm{dd}(15.6,11.4)$ & 148.2 & $6.15 \mathrm{dt}(15.8,7.4)$ & 137.0 & 5.68 ddd $(22.0,14.6,7.0)$ & 134.0 \\
\hline 10 & $6.44 \mathrm{dd}(15.6,10.8)$ & 128.9 & $6.22 \mathrm{~d}(14.3)$ & 131.1 & $3.90 \mathrm{~m}$ & 77.5 \\
\hline 11 & $7.29 \mathrm{dd}(15.6,10.8)$ & 145.4 & $6.22 \mathrm{~d}(14.3)$ & 138.6 & $3.66 \mathrm{~m}$ & 71.6 \\
\hline 12 & $6.15 \mathrm{~d}(15.6)$ & 131.2 & $5.75 \mathrm{~m}$ & 129.8 & $1.13 \mathrm{~d}(6.4)$ & 18.6 \\
\hline 13 & & 201.5 & $4.27 \mathrm{q}(6.4)$ & 68.8 & & \\
\hline 14 & 2.28 overlap & 27.0 & $1.23 \mathrm{~d}(6.4)$ & 23.6 & & \\
\hline $1^{\prime}$ & $3.26 \mathrm{~s}$ & 51.2 & $3.26 \mathrm{~s}$ & 51.1 & $3.25 \mathrm{~s}$ & 51.1 \\
\hline $2^{\prime}$ & & 71.7 & & 71.6 & & 71.7 \\
\hline $3^{\prime} / 4^{\prime}$ & $1.18 \mathrm{~s}$ & 27.2 & $1.18 \mathrm{~s}$ & 27.2 & $1.17 \mathrm{~s}$ & 27.2 \\
\hline
\end{tabular}

Detailed analysis of the ${ }^{1} \mathrm{H}$ and ${ }^{13} \mathrm{C}-\mathrm{NMR}$ data, along with the COSY, HSQC, and HMBC spectra (Figure 2) led to the conclusion that $\mathbf{1}$ was structurally similar to ZP-amide A (6).

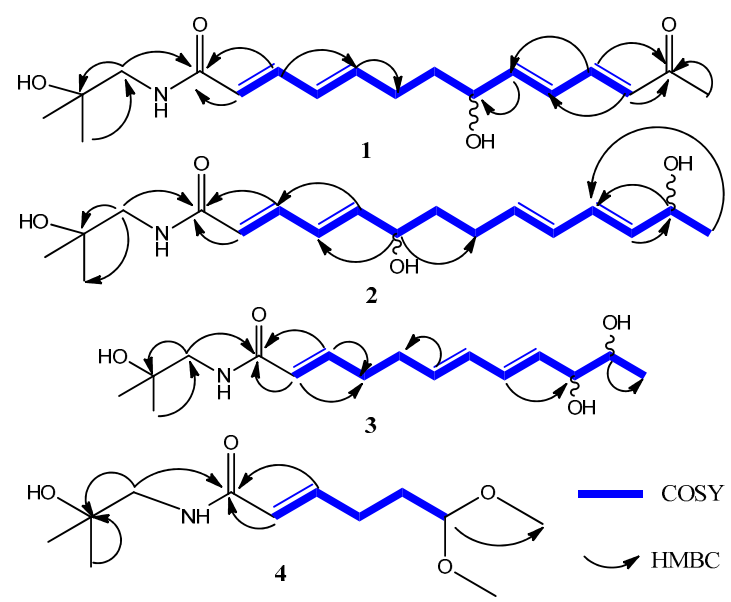

Figure 2. Selected 2D NMR correlations for compounds 1-4. 
The major difference was one more olefinic bond between the C-3 and C-6 positions in the aliphatic chain of $\mathbf{1}$ than in ZP-amide A (6), which was consistent with its molecular formula and degree of unsaturation. The ${ }^{1} \mathrm{H}-{ }^{1} \mathrm{H}$ COSY spectrum (Figure 2) indicated vicinal correlations of $\mathrm{H}-2 / \mathrm{H}-3 / \mathrm{H}-4 / \mathrm{H}-5 / \mathrm{H}-6 / \mathrm{H}-7 / \mathrm{H}-8 / \mathrm{H}-9 / \mathrm{H}-10 / \mathrm{H}-11 / \mathrm{H}-12$ and the HMBC experiment showed correlations from H-1', H-2, and H-3 to C-1, H-9 to C-8 $\left(\delta_{\mathrm{C}} 71.8\right)$, and H-11, H-12 and $\mathrm{H}_{3}-14$ to C-13 (Figure 2), thus suggesting that the locations of the amide, hydroxyl, ketonic carbons to be at C-1, C-8 and $\mathrm{C}-13$, respectively, and the connectivity between the aliphatic acid and the amine moieties. Additionally, the geometry of the $C_{4} / C_{5}$ olefinic bond was deduced to be trans-configured, like those of $C_{2} / C_{3}$, $\mathrm{C}_{9} / \mathrm{C}_{10}$, and $\mathrm{C}_{11} / \mathrm{C}_{12}$ olefinic bond, from the coupling constant $\left(\mathrm{J}_{\mathrm{H}-4 / \mathrm{H}-5}=15.7 \mathrm{~Hz}\right)$. The optical inactivity of this compound indicated that 1 was a racemic mixture. Consequently, compound 1 was identified as $(2 E, 4 E, 9 E, 11 E)-N$-(2-hydroxy-2-methypropyl)-8-hydroxy-13-oxo-2,4,9,11-tetradecatetraenamide, and named zanthoamide A.

Compound 2 had a molecular formula $\mathrm{C}_{18} \mathrm{H}_{29} \mathrm{NO}_{4}$ by HRESIMS at $m / z 346.1961[\mathrm{M}+\mathrm{Na}]^{+}$, indicating five degrees of unsaturation. Comparison of the 1D NMR (Table 1) spectroscopic data of $\mathbf{2}$ with those of $\mathbf{1}$ clearly disclosed that $\mathbf{2}$ was also an aliphatic acid amide. The obvious difference between the two compounds was that the ketone carbonyl at C-13 ( $\left.\delta_{C} 201.5\right)$ in 1 was replaced by a hydroxyl group in 2 , which was confirmed by the upfield shift of $C-13\left(\delta_{C} 68.8\right)$ in 2 , in combination of the ${ }^{1} \mathrm{H}-{ }^{1} \mathrm{H}$ COSY correlations of $\mathrm{H}_{3}-14 / \mathrm{H}-13 / \mathrm{H}-12$ and the HMBC correlations from $\mathrm{H}-13$ to $\mathrm{C}-11$ $\left(\delta_{\mathrm{C}} 145.4\right)$, and $\mathrm{H}-12\left(\delta_{\mathrm{H}} 6.18\right)$ to $\mathrm{C}-13$ in 2 . Moreover, the HSQC spectrum suggested the hydroxyl group to be ascribable to C-6 in 2 rather than to C-8 in 1, as evident from the large downfield chemical shift of C-6 $\left(\delta_{C} 72.4\right)$ and upfield shift of C-8 $\left(\delta_{C} 29.9\right)$ observed in the ${ }^{13} \mathrm{C}-\mathrm{NMR}$ spectrum of 2. This was further confirmed by the COSY correlations of $\mathrm{H}-2 / \mathrm{H}-3 / \mathrm{H}-4 / \mathrm{H}-5 / \mathrm{H}-6$. The assignments of all proton and carbon signals were fully made by $2 \mathrm{D}\left({ }^{1} \mathrm{H}-{ }^{1} \mathrm{H}\right.$ COSY, HSQC, and HMBC) NMR data. The optical inactivity of this compound indicated that 1 was a racemic mixture. Thus, 2 was identified as $(2 E, 4 E, 9 E, 11 E)-N$-(hydroxy-2-methypropyl)-8,13-dihydroxy-2,4,9,11-tetradeca-tetraenamide, and named zanthoamide $B$.

Compound 3 was obtained as a colorless syrup. Its molecular formula $\mathrm{C}_{16} \mathrm{H}_{27} \mathrm{NO}_{4}$ was determined by HRESIMS at $m / z 320.1813[\mathrm{M}+\mathrm{Na}]^{+}$(calcd. for $\mathrm{C}_{16} \mathrm{H}_{27} \mathrm{NO}_{4} \mathrm{Na}, 320.1838$ ). The ${ }^{1} \mathrm{H}$ and ${ }^{13} \mathrm{C}-\mathrm{NMR}$ data of compound 3 were very similar to those of $\mathrm{ZP}$-amide $\mathrm{C}$ (8). The only differences between the two compounds were that the cis-configured olefin at C-6 and C-7 at $\delta_{\mathrm{H}} 5.40(d t, J=11,7 \mathrm{~Hz}, \mathrm{H}-6)$ in 8 was replaced by a trans-configured one at $\delta_{\mathrm{H}} 5.70(d t, J=15.3,7.0 \mathrm{~Hz}, \mathrm{H}-6)$ in 3 . The structure of this compound was confirmed by detailed analysis of the 2D NMR data including its HSQC, HMBC, and ${ }^{1} \mathrm{H}-{ }^{1} \mathrm{H}$ COSY spectra. The optical inactivity of this compound indicated that it was a racemic mixture. The relative configuration of the two asymmetric carbons still remains to be determined. Consequently, 3 was established to be $\left(10^{*}, 11^{*}\right)-(2 E, 6 E, 8 E)$-10,11-dihydroxy- $N$-(2-hydroxy-2,6,8-dodecatrienamide, and named zanthoamide $C$.

Compound 4 was also obtained as a colorless syrup having a molecular formula $\mathrm{C}_{12} \mathrm{H}_{23} \mathrm{NO}_{4}$, as deduced from HRESIMS at $m / z 268.1505[\mathrm{M}+\mathrm{Na}]^{+}$(calcd. for $\mathrm{C}_{12} \mathrm{H}_{23} \mathrm{NO}_{4} \mathrm{Na}$, 268.1525). The ${ }^{1} \mathrm{H}$ and ${ }^{13} \mathrm{C}-\mathrm{NMR}$ spectra of 4 (Table 2), compared with those of 3 , clearly showed that 4 was also an aliphatic acid amide, which contained a rare $\mathrm{C}_{6}$ fatty acid with an acetal group, as evident from the ${ }^{1} \mathrm{H}-{ }^{1} \mathrm{H}$ COSY correlations of $\mathrm{H}-2\left(\delta_{\mathrm{H}} 6.02\right) / \mathrm{H}-3\left(\delta_{\mathrm{H}} 6.80\right) / \mathrm{H}_{2}-4\left(\delta_{\mathrm{H}} 2.25\right) / \mathrm{H}_{2}-5\left(\delta_{\mathrm{H}} 1.74\right) / \mathrm{H}-6\left(\delta_{\mathrm{H}} 4.39\right)$ as well as from the ${ }^{1} \mathrm{H}$ and ${ }^{13} \mathrm{C}-\mathrm{NMR}$ data of an acetal group $\left(\delta_{\mathrm{H}} 4.39, J=5.7 \mathrm{~Hz}, \mathrm{H}-6 ; \delta_{\mathrm{C}} 105.5, \mathrm{C}-6 ; \delta_{\mathrm{H}} 3.33\right.$ and $\delta_{\mathrm{C}} 53.6$, $\left.2 \times \mathrm{OCH}_{3}\right)$. The presence of the acetal moiety at C-6 was supported by the HMBC correlation of $\mathrm{OCH}_{3}$ $\left(\delta_{\mathrm{C}} 53.6\right)$ with H-6 $\left(\delta_{\mathrm{H}} 4.39\right)$ obtained in $\mathrm{MeOH}-d_{4}$ solvent. However, due to overlapping between the methoxyl and $\mathrm{MeOH}-d_{4}$ signals, consequently, we measured the ${ }^{1} \mathrm{H}-\mathrm{NMR}$ spectrum (see Figure S25 in Supplementary Materials) with DMSO- $d_{6}$ as solvent, in which the six protons of the two methoxyl groups as a strong singlet were observed at $\delta_{\mathrm{H}}$ 3.22. Therefore, compound 4 was identified as (2E)-6,6-dimethoxy-N-(2-hydroxy-2-methylpropyl)-2-hexenamide, and named zanthoamide D. 
Table 2. ${ }^{1} \mathrm{H}-(500 \mathrm{MHz})$ and ${ }^{13} \mathrm{C}-(125 \mathrm{MHz})$ NMR Data of Compound 4 ( $\left.\delta \mathrm{ppm}\right)$.

\begin{tabular}{|c|c|c|c|}
\hline No. & $\delta_{H}$ Multi. $(J \text { in } \mathrm{Hz})^{a}$ & $\delta_{C}{ }^{a}$ & $\delta_{H}$ Multi. $(J \text { in } \mathrm{Hz})^{b}$ \\
\hline 1 & & 169.0 & \\
\hline 2 & $6.02 \mathrm{dt}(15.4,1.5)$ & 124.9 & $6.03 \mathrm{~d}(15.5)$ \\
\hline 3 & $6.80 \mathrm{dt}(15.4,6.9)$ & 145.1 & $6.61 \mathrm{~m}$ \\
\hline 4 & $2.25 \mathrm{td}(8.4,1.5)$ & 28.1 & $2.13 \mathrm{dd}(14.9,6.6)$ \\
\hline 5 & $1.74 \mathrm{~m}$ & 32.4 & $1.63 \mathrm{dd}(14.4,6.5)$ \\
\hline 6 & $4.39 \mathrm{t}(5.7)$ & 105.5 & $4.34 \mathrm{t}(5.5)$ \\
\hline $1^{\prime}$ & $3.25 \mathrm{~s}$ & 51.1 & $3.07 \mathrm{~d}(6.0)$ \\
\hline $2^{\prime}$ & & 71.6 & \\
\hline $3^{\prime} / 4^{\prime}$ & $1.17 \mathrm{~s}$ & 27.2 & $1.04 \mathrm{~s}$ \\
\hline $2 \times \mathrm{OCH}_{3}$ & $3.33^{c}$ & 53.6 & $3.22 \mathrm{~s}$ \\
\hline
\end{tabular}

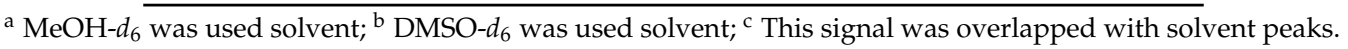

Unsaturated fatty acid amides are characteristic constituents of the genus Zanthoxylum, which contains more than 50 such compounds [16,22-25]. Nearly all aliphatic acid amides from the Zanthoxylum species have been isolated as racemates, and their absolute configurations have yet to be determined [16]. To the best of our knowledge, compound 4 is the first example of a fatty acid amide containing a $\mathrm{C}_{6}$ fatty acid unit found in the genus Zanthoxylum. It should be noted that 4 possesses an acetal group in its structure. Owing to contact with methanol during the extraction and purification processes, it may be a new fatty acid amide artifact presumably formed during these processes.

\subsection{Biological Activity Assays}

Compounds 1-12 were evaluated for their inhibitory activities against nitric oxide (NO) production in LPS-activated RAW264.7 cells and their cytotoxicities against two human cancer cell lines [26,27]. This assay indicated that compounds 1, 5, 6, and 12 exhibited inhibitory activities against NO production in LPS-activated RAW264.7 macrophages, with $\mathrm{IC}_{50}$ values of $48.7 \pm 0.32,27.1 \pm 1.15$, $49.8 \pm 0.38$, and $39.4 \pm 0.63 \mu \mathrm{M}$, respectively, while the other compounds were inactive $\left(\mathrm{IC}_{50}>60 \mu \mathrm{M}\right)$ (Table 3). Among them, 5 exhibited the highest inhibitory activity. The observations suggested that the unsaturated longer aliphatic chain without oxygen functions appears to play an important role in inhibiting NO production (5 vs. 1 and 2 ).

Table 3. Inhibitory effects of compounds 1-12 on NO production by LPS-stimulated RAW264.7 cells.

\begin{tabular}{cc}
\hline No. & IC $_{\mathbf{5 0}}$ Values $(\boldsymbol{\mu M})$ \\
\hline $\mathbf{1}$ & $48.7 \pm 0.32$ \\
$\mathbf{2}$ & $\mathrm{NT}$ \\
$\mathbf{3}$ & $\mathrm{NT}$ \\
$\mathbf{4}$ & $\mathrm{NT}$ \\
$\mathbf{5}$ & $27.1 \pm 1.15$ \\
$\mathbf{6}$ & $49.8 \pm 0.38$ \\
$\mathbf{7}$ & $\mathrm{NT}$ \\
$\mathbf{8}$ & $112.9 \pm 0.91$ \\
$\mathbf{9}$ & $62.3 \pm 1.12$ \\
$\mathbf{1 0}$ & $\mathrm{NT}$ \\
$\mathbf{1 1}$ & $\mathrm{NT}$ \\
$\mathbf{1 2}$ & $39.4 \pm 0.63$ \\
Dexamethasone & $1.54 \pm 0.07$
\end{tabular}

Dexsamethasone was used as positive control. Data presented is the mean \pm S.D. of samples run in triplicate. Compared with control $p<0.001$. NT: not tested.

Additionally, the cytotoxicity of each compound was examined. Cell viability was measured by the MTT colorimetric assay. Compounds 1-12 had no significant cytotoxicity in LPS-stimulated RAW 
264.7 cells at concentrations up to $50.0 \mu \mathrm{M}$ (data not shown). At $50 \mu \mathrm{M}$, the cytotoxic activities against human colon cancer (HCT116) and human prostate cancer (PC-3) cells were also tested, and none of them exhibited detectable cytotoxicity.

It has been reported that four amides-ZP-amide A (6), ZP-amide C (7), ZP-amide D (9), and ZP-amide E (10) -inhibited the growth of a neurofibromatosis type 1 (NF1)-and p53-deficient mouse glioma cell line at non-cytotoxic concentrations [14]. In addition, ZP-amide A (6) and ZP-amide D (9) exerted significant anti-inflammatory effects through enhancing the peroxisome proliferator-activated receptor (PPAR) transactivational activity with $\mathrm{EC}_{50}$ values of 19.1 and $12.0 \mu \mathrm{M}$, respectively [16]. The findings further suggest that alkylamides are the major anti-inflammatory components of the edible spice, Z. bungeanum, which was also substantiated by our observations that some compounds (i.e., $\mathbf{5}$ and 12) display NO-inhibitory activity. It is well known that NO is a crucial cellular-signaling molecule associated with several physiological and pathological processes [28]. It is therefore a fundamental component in the fields of neuroscience, physiology, and immunology [29]. NO has been shown to activate NF- $\mathrm{KB}$ in peripheral blood mononuclear cells, an important transcription factor in iNOS gene expression in response to inflammation [30]. So suppression of NO production was a direct indicator of those compounds to resist inflammation.

\section{Experimental Section}

\subsection{General Procedures}

Optical rotations were measured using an Autopol III automatic polarimeter (Rudolph Research Analytical, Hackettstown, NJ, USA). UV spectrum were obtained on an Evolution-300 UV-visible spectrophotometer (Thermo Fisher Scientific Inc., Waltham, MA, USA) and a Tensor 27 FT-IR spectrometer (Bruker Optics, Germany) in KBr pellets, respectively. NMR spectra were measured on an Avance III 500 instruments (Bruker Daltonics Inc., Bremen, Germany), with tetramethylsilane (TMS) as an internal standard at room temperature. ESI-MS were performed on a LTQ Fleet instrument (Thermo Fisher Scientific Inc., Waltham, MA, USA), and HRESIMS were obtained on a Thermo Fisher Scientific Q-TOF mass spectrometer (Thermo Fisher Scientific Inc., Waltham, MA, USA). Semipreparative HPLC was performed on a Waters 1100 liquid chromatography system (Waters Corp., Milford, MA, USA) equipped with a Hypersil BDS $\mathrm{C}_{18}$ column $(4.6 \mathrm{~mm} \times 250 \mathrm{~mm}$ and $10.0 \mathrm{~mm} \times 250 \mathrm{~mm}, 5 \mu \mathrm{m}$, (Thermo Fisher Scientific Inc., Waltham, MA, USA). Column chromatography (CC) was performed on silica gel $(90-150 \mu \mathrm{m})$ (Qingdao Marine Chemical Inc., Qingdao, China), Sephadex LH-20 (40-70 $\mu \mathrm{m}$; Amersham Pharmacia Biotech AB, Uppsala, Sweden), and Lichroprep RP-18 gel (40-63 $\mu \mathrm{m}$; Merck, Darmstadt, Germany). GF $_{254}$ plates (Qingdao Marine Chemical Inc.) were used for thin-layer chromatography (TLC). Preparative TLC (PTLC) was carried out on silica gel $60 \mathrm{GF}_{254}$ (Qingdao Marine Chemical, Ltd.). Finally, compounds were visualized under UV light $(254 \mathrm{~nm})$ and by dipping into $10 \% \mathrm{H}_{2} \mathrm{SO}_{4}$ in ethanol followed by heating.

\subsection{Plant Materials}

The pericarps of Z. bungeanum were collected from Feng County (Shaanxi, China), in July 2013 and authenticated by Prof. Zai-Min Jiang (Plant Laboratory, College of Life Sciences, Northwest A\&F University, Shaanxi, China). A voucher specimen (LXY-0156) was deposited in our laboratory.

\subsection{Extraction, Isolation and Purification}

The air-dried and powdered pericarps of Z. bungeanum $(1.0 \mathrm{~kg})$ were extracted three times with $95 \%$ ethanol $(2.5 \mathrm{~L} \times 3)$ for $24 \mathrm{~h}$. A crude extract was partitioned between $\mathrm{MeOH}$ and petroleum ether (1:1) to afford the $\mathrm{MeOH}$-soluble extract $(73.0 \mathrm{~g})$, which was dissolved in water. The aqueous syrup was adjusted to $\mathrm{pH} 2$ with $2 \% \mathrm{HCl}$ and then filtered. The filtrate, adjusted to $\mathrm{pH} 9$ with $20 \% \mathrm{NaOH}$, was extracted with $\mathrm{CHCl}_{3}$ to afford an extract $(39.2 \mathrm{~g}$ ). The extract was subjected to silica gel column chromatography (CC) eluting with petroleum ether (PE)-EtOAc (5:1, 2:1, 1:1 and 1:2) to 
give two fractions (A and B). Fraction A (28.6 g) was separated by silica gel column with $\mathrm{CHCl}_{3}-\mathrm{MeOH}$ (50:1, 40:1, 30:1) to afford three fractions (Fr.A1-A3). Chromatography of Fr.A1 (2.88 g) on silica gel column with PE-EtOAc (2:1, 1:1, 1:2, 1:3, 1:4) gave four fractions (Fr.1-4). Fr1. (622 mg) was separated by CC on Sephadex LH-20 (MeOH) to obtain three fractions (Fr.1-1 to Fr.1-3). Fr.1-1 was purified by PTLC $\left(\mathrm{CHCl}_{3}-\mathrm{MeOH} 20: 1\right)$ and HPLC on $\mathrm{C}_{18}$ column $(4.6 \times 250 \mathrm{~mm})(60 \% \mathrm{MeOH})$ to yield $4\left(5.2 \mathrm{mg}, \mathrm{t}_{R} 7.8 \mathrm{~min}\right)$. Similarly, chromatographies of Fr.1-2 on silica gel column $\left(\mathrm{CHCl}_{3}-\mathrm{MeOH} 35: 1\right)$, $\mathrm{LH}-20(\mathrm{MeOH})$ and HPLC (55\% MeOH) gave $6(15.9 \mathrm{mg}), 8(18 \mathrm{mg})$, and $9(20 \mathrm{mg})$. Fr.2 (3.70 g) was subjected to RP-C18 with $\mathrm{MeOH}-\mathrm{H}_{2} \mathrm{O}$ (10:90-100:0) to provide two fractions (Fr.2-1 to Fr.2-2). Fr.2-1 (1.92 g) was successively separated by CC on RP-C18 (40\% MeOH), PTLC $\left(\mathrm{CHCl}_{3}-\mathrm{MeOH} 25: 1\right)$ and HPLC $(60 \% \mathrm{MeOH})$ to give $12(120.9 \mathrm{mg})$ and $7(26 \mathrm{mg})$. Meanwhile, Fr.2-2 (600 mg) was separated by CC on LH-20 (MeOH), silica gel $\left(\mathrm{CHCl}_{3}-\mathrm{MeOH} 20: 1\right)$ and then $\mathrm{HPLC}(55 \% \mathrm{MeOH}$, flow rate $10 \mathrm{~mL} / \mathrm{min})$ to yield $11(5.1 \mathrm{mg})$. Fr.3 (6.32 g) provided two subfractions through CC on RP-C18 $(\mathrm{MeOH})$, whose first subfraction was successively subjected to LH-20 (MeOH), RP-C18 (40\% MeOH), silica gel CC $\left(\mathrm{CHCl}_{3}-\mathrm{MeOH} 30: 1\right)$ and HPLC $(65 \% \mathrm{MeOH})$ to afford $\mathbf{1}(5 \mathrm{mg}), \mathbf{2}(20 \mathrm{mg})$, and $\mathbf{3}(10 \mathrm{mg})$. The other subfraction was separated by HPLC $(60 \% \mathrm{MeOH})$ to obtain $10(16 \mathrm{mg})$. Compound $5(20 \mathrm{mg})$ was obtained from Fr.4 $(19.6 \mathrm{~g})$ through LH-20 (MeOH), silica gel (petroleum ether-EtOAc 2:1), and RP-C18 (80\% MeOH) CC.

\subsection{Identification}

Zanthoamide A (1). Pale yellow oil; $[\alpha]_{D}^{30} \pm 0(c 0.10, \mathrm{MeOH}) ; \mathrm{UV}(\mathrm{MeOH}) \lambda_{\max } \mathrm{nm}(\log \varepsilon): 268$ (1.313); IR (film) $v_{\max } 3370,2972,2934,1665,1545,1382,1268,1178,1028,980,907,768,586 \mathrm{~cm}^{-1} ;{ }^{1} \mathrm{H}-$ and ${ }^{13} \mathrm{C}-\mathrm{NMR}$ data, see Table 1; positive-ion HRESIMS $m / z 344.1810[\mathrm{M}+\mathrm{Na}]^{+}$(calcd for $\mathrm{C}_{18} \mathrm{H}_{27} \mathrm{NO}_{4} \mathrm{Na}$, 344.1838).

Zanthoamide B (2). Pale yellow syrup; $[\alpha]_{D}^{30} \pm 0(c 0.12, \mathrm{MeOH}) ; \mathrm{UV}(\mathrm{MeOH}) \lambda_{\max } \mathrm{nm}(\log \varepsilon)$ : 231 (1.342); IR (film) $v_{\max } 3377,2973,2932,1663,1549,1382,1267,1178,1028,907,768,624 \mathrm{~cm}^{-1} ;{ }^{1} \mathrm{H}-$ and ${ }^{13} \mathrm{C}-\mathrm{NMR}$ data, see Table 1; positive-ion HRESIMS $m / z 346.1961[\mathrm{M}+\mathrm{Na}]^{+}$(calcd for $\mathrm{C}_{18} \mathrm{H}_{29} \mathrm{NO}_{4} \mathrm{Na}$, 346.1994).

Zanthoamide C (3). Colorless syrup, $[\alpha]_{D}^{29} \pm 0(c 0.12, \mathrm{MeOH}) ; \mathrm{UV}(\mathrm{MeOH}) \lambda_{\max } \mathrm{nm}(\log \varepsilon): 230$ (1.342); IR (film) $v_{\max } 3354,2973,2930,1710,1667,1634,1549,1380,1221,1178,1074,1030,980,907,768$, $651 \mathrm{~cm}^{-1} ;{ }^{1} \mathrm{H}$ - and ${ }^{13} \mathrm{C}-\mathrm{NMR}$ data, see Table 1 ; positive-ion HRESIMS $m / z 320.1813\left[\mathrm{M}+\mathrm{Na}^{+}\right.$ (calcd for $\mathrm{C}_{16} \mathrm{H}_{27} \mathrm{NO}_{4} \mathrm{Na}$, 320.1838).

Zanthoamide $D$ (4). Colorless syrup $[\alpha]_{D}^{30} \pm 0(c 0.16, \mathrm{MeOH}) ; \mathrm{UV}(\mathrm{MeOH}) \lambda_{\max } \mathrm{nm}(\log \varepsilon)$ : 268 (1.313); IR (film) $v_{\max } 3377,2973,2932,1669,1547,1463,1267,980,615 \mathrm{~cm}^{-1} ;{ }^{1} \mathrm{H}$ and ${ }^{13} \mathrm{C}-\mathrm{NMR}$ data, see Table 2; positive-ion HRESIMS $m / z 268.1505[\mathrm{M}+\mathrm{Na}]^{+}$(calcd for $\mathrm{C}_{12} \mathrm{H}_{23} \mathrm{NO}_{4} \mathrm{Na}, 268.1525$ ).

\subsection{Nitric Oxide Production Inhibition Assay}

RAW 264.7 cells were seeded at a density of $5 \times 10^{5}$-cells/well in 24 well plates and incubated for $12 \mathrm{~h}$ at $37^{\circ} \mathrm{C}$ and $5 \% \mathrm{CO}_{2}$ [26]. Then media of each well were aspirated and fresh FBS-free DMEM media were replaced. Compounds 1-12 $(20 \mu \mathrm{M})$ were prepared in FBS-free DMEM to give a total volume of $500 \mu \mathrm{L}$ in each well of a microtiter plate. After $1 \mathrm{~h}$ treatment, cells were stimulated with $100 \mathrm{ng} / \mathrm{mL}$ of LPS for $24 \mathrm{~h}$. Nitrite concentrations were determined from a standard curve using sodium nitrite at concentrations ranging from 0 to $120 \mu \mathrm{M}$. The absorbance was measured at $540 \mathrm{~nm}$ in a microplatereader (Biotek, Winooski, VT, USA). The amount of nitrite inthe media was calculated from sodium nitritestandard curve. The data show the mean \pm S.D. of three independent experiments. $p<0.05$, and $p<0.001$. The values expressed are means of three replicate determinations \pm standard deviation. The data were evaluated with SPSS 20.0 (SPSS Inc., Chicago, IL, USA).

\subsection{Cytotoxicity Assays}

The cytotoxicity assay was performed in 96-well microplates using the 3-(4,5-dimethylthiazol-2-yl)2,5-diphenyltetrazolium bromide (MTT) method [27]. Compounds 1-12 were evaluated for their 
cytotoxicity against human colon cancer (HCT116) and human prostate cancer (PC-3) cells. Cells were cultured in RPMI-1640 or in DMEM medium (Hyclone, Kerrville, TX, USA) supplemented with $10 \%$ fetal bovine serum (Hyclone) in $5 \% \mathrm{CO}_{2}$ at $37^{\circ} \mathrm{C}$.

\section{Conclusions}

In conclusion, we have identified 12 lipophilic alkyamides of the sandshool class from the pericarps of $Z$. bungeanum, including four new ones 1-4, which we have named zanthoamides A-D. NO inhibitory activity was observed for these alkyamides (compounds 1, 5, 6, and 12) in LPS-stimulated RAW 264.7 cells, of which 5 was the best inhibitor. The results demonstrated that these fatty acid amides might play important roles in anti-inflammatory activity of the pericarps of Z. bungeanum.

Supplementary Materials: NMR and HRESIMS spectra for compounds 1-4 can be accessed at: http:/ /www.mdpi.com/1420-3049/21/10/1416/s1.

Acknowledgments: This work was financially supported by Special Fund for Forestry Research in the Public Interest (No. 201304706) and Medicinal Plant Resources Nursery Construction and Improved Variety of Zanthoxylum (Qian ZY[2012] no. 3002) as well as the Program of Science \& Technology of Shaanxi Prevince (2013SF2-15).

Author Contributions: J.M.G. and A.Z.W. designed research; Y.W., C.H.L., Y.N.S., Y.H.K and B.L. performed research and analyzed the data; J.M.G. wrote the paper. All authors read and approved the final manuscript.

Conflicts of Interest: The authors declare no conflict of interest.

\section{References}

1. Bader, M.; Stark, T.D.; Dawid, C.; Lösch, S.; Hofmann, T. All-trans-configuration in Zanthoxylum alkylamides swaps the tingling with a numbing sensation and diminishes salivation. J. Agric. Food Chem. 2014, 62, 2479-2488. [CrossRef] [PubMed]

2. Yang, X. Aroma constituents and alkylamides of red and green huajiao (Zanthoxylum bungeanum and Zanthoxylum schinifolium). J. Agric. Food. Chem. 2008, 56, 1689-1696. [CrossRef] [PubMed]

3. Kato, A.; Moriyasu, M.; Ichimaru, M.; Nishiyama, Y. Isolation of alkaloidal constituents of Zanthoxylum usambarense and Zanthoxylum chalybeum using ion-pair HPLC. J. Nat. Prod. 1996, 59, 316-318. [CrossRef]

4. Huang, S.; Zhao, L.; Zhou, X.L.; Ying, M.; Wang, C.J.; Weng, J. New alkylamides from pericarps of Zanthoxylum bungeanum. Chin. Chem. Lett. 2012, 23, 1247-1250. [CrossRef]

5. Xiong, Q.; Shi, D.; Yamamoto, H.; Mizuno, M. Alkylamides from pericarps of Zanthoxylum bungeanum. Phytochemistry 1997, 46, 1123-1126. [CrossRef]

6. Zhao, Z.F.; Zhu, R.X.; Zhong, K.; He, Q.; Luo, A.M.; Gao, H. Characterization and comparison of the pungent components in commercial Zanthoxylum bungeanum oil and Zanthoxylum schinifolium oil. J. Food. Sci. 2013, 78, C1516-C1522. [CrossRef] [PubMed]

7. Hatano, T.; Inada, K.; Ogawa, T.O.; Ito, H.; Yoshida, T. Aliphatic acid amides of the fruits of Zanthoxylum piperitum. Phytochemistry 2004, 65, 2599-2604. [CrossRef] [PubMed]

8. Lan, Y.; Wu, Q.; Mao, Y.Q.; Wang, Q.; An, J.; Chen, Y.Y.; Wang, W.P.; Zhao, B.C.; Liu, N.; Zhang, Y.W. Cytotoxicity and enhancement activity of essential oil from Zanthoxylum bungeanum Maxim. as a natural transdermal penetration enhancer. J. Zhejiang Univ. Sci. B 2014, 15, 153-164. [CrossRef] [PubMed]

9. Yang, L.C.; Li, R.; Tan, J.; Jiang, Z.T. Polyphenolics composition of the leaves of Zanthoxylum bungeanum Maxim. grown in Hebei, China, and their radical scavenging activities. J. Agric. Food Chem. 2013, 61, 1772-1778. [CrossRef] [PubMed]

10. Navarrete, A.; Hong, E. Anthelmintic properties of $\alpha$-sanshool from Zanthoxylum liebmannianum. Planta Med. 1996, 62, 250-251. [CrossRef] [PubMed]

11. Hashimoto, K.; Satoh, K.; Kase, Y.; Ishige, A.; Kubo, M.; Sasaki, H.; Nishikawa, S.; Kurosawa, S.; Yakabi, K.; Nakamura, T. Modulatory effect of aliphatic acid amides from Zanthoxylum piperitum on isolated gastrointestinal tract. Planta Med. 2001, 67, 179-181. [CrossRef] [PubMed]

12. Jang, K.H.; Chang, Y.H.; Kim, D.D.; Oh, K.B.; Oh, U.; Shin, J. New polyunsaturated fatty acid amides isolated from the seeds of Zanthoxylum piperitum. Arch. Pharm. Res. 2008, 31, 569-572. [CrossRef] [PubMed] 
13. Dossou, K.S.S.; Devkota, K.P.; Morton, C.; Egan, J.M.; Lu, G.; Beutler, J.A.; Moaddel, R. Identification of CB1/CB2 ligands from Zanthoxylum bungeanum. J. Nat. Prod. 2013, 76, 2060-2064. [CrossRef] [PubMed]

14. Devkota, K.P.; Wilson, J.; Henrich, C.J.; McMahon, J.B.; Reilly, K.M.; Beutler, J.A. Isobutylhydroxyamides from the pericarp of Nepalese Zanthoxylum armatum inhibit NF1-defective tumor cell line growth. J. Nat. Prod. 2013, 76, 59-63. [CrossRef] [PubMed]

15. Park, Y.D.; Lee, W.S.; An, S.; Jeong, T.S. Human acyl-CoA: Cholesterol acyltransferase inhibitory activities of aliphatic acid amides from Zanthoxylum piperitum DC. Biol. Pharm. Bull. 2007, 30, 205-207. [CrossRef] [PubMed]

16. Yang, S.Y.; Tai, B.H.; Song, S.B.; Li, W.; Yan, X.T.; Sun, Y.N.; Thao, N.P.; Kim, Y.H. NF-kB activation and PPAR transactivational effects of a new aliphatic acid amide from pericarps of Zanthoxylum piperitum. Bull. Korean Chem. Soc. 2014, 35, 2361-2366. [CrossRef]

17. Tian, J.M.; Wang, Y.; Xu, Y.Z.; Yu, Z.C.; Wei, A.Z.; Zhang, W.M.; Gao, J.M. Characterization of isobutylhydroxyamides with NGF-potentiating activity from Zanthoxylum bungeanum. Bioorg. Med. Chem. Lett. 2016, 26, 338-342. [CrossRef] [PubMed]

18. Tang, J.J.; Zhang, F.Y.; Wang, D.M.; Tian, J.M.; Dong, S.; Gao, J.M. Semisynthesis and antifeedant activity of new derivatives of a dihydro- $\beta$-agarofuran from Parnassia wightiana. Int. J. Mol. Sci. 2013, 14, 19484-19493. [CrossRef] [PubMed]

19. Liu, H.W.; Yu, X.Z.; Padula, D.; Pescitelli, G.; Lin, Z.W.; Wang, F.; Ding, K.; Lei, M.; Gao, J.M. Lignans from Schisandra sphenathera Rehd. et Wils. and semisynthetic schisantherin A analogues: Absolute configuration, and their estrogenic and anti-proliferative activity. Eur. J. Med. Chem. 2013, 59, 265-273. [CrossRef] [PubMed]

20. Bai, M.-M.; Shi, W.; Tian, J.-M.; Lei, M.; Kim, J.H.; Sun, Y.N.; Kim, Y.H.; Gao, J.-M. Soluble epoxide hydrolase inhibitory and anti-inflammatory components from the leaves of Eucommia ulmoides Oliver (Duzhong). J. Agric. Food Chem. 2015, 63, 2198-2205. [CrossRef] [PubMed]

21. Wang, D.-M.; Zhang, C.-C.; Zhang, Q.; Shafiq, N.; Pescitelli, G.; Li, D.-W.; Gao, J.-M. Wightianines A-E, dihydro- $\beta$-agarofuran sesquiterpenes from Parnassia wightiana, and their antifungal and insecticidal activities. J. Agric. Food Chem. 2014, 62, 6669-6676. [CrossRef] [PubMed]

22. Yasuda, I.; Takeya, K.; Itokawa, H. Distribution of unsaturated aliphatic acid amides in Japanese Zanthoxylum species. Phytochemistry 1982, 21, 1295-1298. [CrossRef]

23. Chen, I.-S.; Chen, T.-L.; Lin, W.-Y.; Tsai, I.-L.; Chen, Y.-C. Isobutylamides from the fruit of Zanthoxylum integrifoliolum. Phytochemistry 1999, 52, 357-360. [CrossRef]

24. Kashiwada, Y.; Ito, C.; Katagiri, H.; Mase, I.; Komatsu, K.; Namba, T.; Ikeshiro, Y. Amides of the fruit of Zanthoxylum spp. Phytochemistry 1997, 44, 1125-1127. [CrossRef]

25. Mizutani, K.; Fukunaga, Y.; Tanaka, O.; Takasugi, N.; Saruwatari, Y.; Fuwa, T.; Yamauchi, T.; Wang, J.; Jia, M.R.; Li, F.-Y.; et al. Amides from haujiao, pericarps of Zanthoxylum bungeanum Maxim. Chem. Pharm. Bull. 1988, 36, 2362-2365. [CrossRef]

26. Kim, Y.H.; Choi, K.H.; Park, J.W.; Kwon, T.K. LY294002 inhibits LPS-induced NO production through a inhibition of NF-kB activation: Independent mechanism of phosphatidylinositol 3-kinase. Immunol. Lett. 2005, 99, 45-50. [CrossRef] [PubMed]

27. Mosmann, T. Rapid colorimetric assay for cellular growth and survival: Application to proliferation and cytotoxicity assays. J. Immunol. Methods 1983, 65, 55-63. [CrossRef]

28. Hou, Y.C.; Janczuk, A.; Wang, P.G. Current trends in the development of nitric oxide donors. Curr. Pharm. Des. 1999, 5, 417-441.

29. Culotta, E.; Koshland, D.E., Jr. NO news is good news. Science 1992, 258, 1862-1864. [CrossRef] [PubMed]

30. Kaibori, M.; Sakitani, K.; Oda, M.; Kamiyama, Y.; Masu, Y.; Nishizawa, M.; Ito, S.; Okumura, T. Immunosuppressant FK506 inhibits inducible nitric oxide synthase gene expression at a step of NF- $\mathrm{KB}$ activation in rat hepatocytes. J. Hepatol. 1999, 30, 1138-1145. [CrossRef]

Sample Availability: Not available.

(C) 2016 by the authors; licensee MDPI, Basel, Switzerland. This article is an open access article distributed under the terms and conditions of the Creative Commons Attribution (CC-BY) license (http://creativecommons.org/licenses/by/4.0/). 